Pak. j. sci. ind. res. Ser. A: phys. sci. 201356 (3) 138-143

\title{
A Comparative Study of the Chemical Composition of Entada pursaetha and Pentaclethra macrophylla Seeds and Seed Oils
}

\author{
Ibironke Adetolu Ajayi* and Rotimi Ayodele Oderinde \\ Industrial Unit, Chemistry Department, Faculty of Science, University of Ibadan, Ibadan, Nigeria
}

(received April 19, 2012; revised October 6, 2012; accepted November 13, 2012)

\begin{abstract}
The proximate, physicochemical, mineral element and fatty acid composition of seeds and seed oils of Entada pursaetha and Pentaclethra macrophylla have been analysed and compared in order to establish any similarities/differences in their chemical composition and to evaluate the possibility of their suitability for nutritional or industrial purposes. The proximate analyses of the seeds showed that the oil yield of P. macrophylla: $40.21 \mathrm{mg} / 100 \mathrm{~g}$ is by far greater than that of E. pursaetha: $4.26 \mathrm{mg} / 100 \mathrm{~g}$ but the carbohydrate content is vice versa (E. pursaetha: $45.36 \mathrm{mg} / 100 \mathrm{~g}$; P. macrophylla: $3.84 \mathrm{mg} / 100 \mathrm{~g}$ ). The protein content of both seeds is high $(23.19-33.00 \mathrm{mg} / 100 \mathrm{~g})$ and is greater than those of high protein animal sources like beef, oyster, pork and marine fishes. The physicochemical properties of the oils are comparable with those of conventional oils and suggest the suitability of these oils as edible oils. Results of the analysis for the mineral element contents of the flour of both seeds showed that potassium is the most prevalent mineral present in the two seeds followed by magnesium for P. macrophylla and phosphorus for E. pursaetha. Analysis of the oils for fatty acids indicates that both oils contain more of unsaturated fatty acids than saturated ones. This is of great nutritional significance.
\end{abstract}

Keywords: Entada pursaetha, Pentaclethra macrophylla, comparative study, composition, fatty acid, seed oils

\section{Introduction}

Plant seeds are important sources of oils of nutritional and pharmaceutical importance. Lipid and lipid related compounds play essential role in disease prevention and growth. The search for lesser known underutilised crops, many of which are potentially valuable as human and animal foods, has been intensified to maintain a balance between population growth and agricultural productivity, particularly in the tropical and sub-tropical areas of the world. Seeds have nutritive and calorific values, which make them necessary in diets. Fats make a meal more satisfying, enrich its flavour and delay the onset of hunger.

Entada pursaetha and Pentaclethra macrophylla are both legumes belonging to the family Mimosaceae. E. pursaetha, called Pandoro or Eso akiiti in Yoruba language of Nigeria, is a lofty wood climber with very stout and enormous straight, woody segmented pods. The fruits, just like most Mimosaceae are mostly elongated pods, fleshly, woody, leathery or papery containing several seeds and splitting open in the majority of cases. The African oil bean, P. macrophylla, is a tropical tree found

*Author for correspondence; E-mail: frajayi@yahoo.com mostly in the southern and middle belt regions of Nigeria and in other coastal parts of West and Central Africa (Keay, 1989). The tree is recognized by peasant farmers in these parts of the country for its soil improvement properties and as a component of an agro-forestry system (Okafor and Fernandez, 1987). There exist in literature reports on some aspects of E. pursaetha and $P$. macrophylla by Ajayi et al. (2002) and Oderinde and Ajayi (1998) and other several authors (Asoegwu et al., 2006; Odoemelam, 2005; Mbajunwa et al., 1998; Mbajunwa, 1995) but no recent work has been reported on the comparative study of the chemical composition of E. pursaetha and P. macrophylla seeds and seed oils. This work therefore, reports on a comparative study of the chemical composition of E. pursaetha and $P$. macrophylla seeds and seed oils.

\section{Materials and Methods}

Collection of samples. The seeds of $P$. macrophylla and $E$. pursaetha were purchased from local markets in Ibadan, Oyo State of Nigeria, while the seeds of $E$. pursaetha were picked around the premises of University of Ibadan, Ibadan, Nigeria. The seeds were identified in the herbarium unit of Botany Department, Faculty 
of Science, University of Ibadan. The concentrated acids, $\mathrm{HClO}_{4}$ (BDH Laboratories Supplies, England) and $\mathrm{HNO}_{3}$ (GFS Chemicals, Inc. Columbus) used in this study were of analytical reagent grade.

Sample preparation. The seeds were cracked to remove the brown and milky coloured kernels from $P$. macrophylla and E. pursaetha. They were ground to powder with the use of Hammer mill (British Jeffrey Diamond Ltd, Sternnard works, Wakefield, England) and were then stored in polythene bag and kept in fridge until needed for analysis.

Extraction. The oils were extracted from the seeds with a soxhlet extractor using petroleum ether $\left(40-60{ }^{\circ} \mathrm{C}\right)$. The oils obtained, after distilling off the hexane, was stored in a labeled flask.

Proximate analysis. All analyses were carried out in Chemistry Department, University of Ibadan except protein determination which was carried out in Human Nutrition Department of the same University. Moisture, oil, protein, ash and crude fibre contents of the seeds were analysed according to AOAC (1984); the method of Idouraine et al. (1996) was followed in determining carbohydrate contents of the seeds.

Physicochemical characteristics. The methods of analyses for free fatty acid, saponification, peroxide and acid values are as outlined by Ajayi et al. (2004). For iodine value (AOAC, 1984), $0.20 \mathrm{~g}$ of the oil was taken into a glass-stoppered flask and dissolved in $15 \mathrm{~mL}$ carbon tetrachloride, $25 \mathrm{~mL}$ of Wijs' solution was added; the flask was stoppered and allowed to stand for $2 \mathrm{~h}$ at $25{ }^{\circ} \mathrm{C}$ after which $20 \mathrm{~mL}$ of $10 \% \mathrm{KI}$ in water was added. The mixture was titrated with $0.1 \mathrm{M} \mathrm{Na}_{2} \mathrm{~S}_{2} \mathrm{O}_{3}$ using starch indicator. A blank determination was carried out. The iodine value was calculated as follows:

Iodine value $=12.69 \mathrm{M}\left(\mathrm{V}_{2}-\mathrm{V}_{1}\right) / \mathrm{W}($ Ajayi et al., 2004)

where:

$\mathrm{M}=$ molarity of thiosulphate

$\mathrm{V}_{1}=$ volume (in $\mathrm{mL}$ ) of thiosulphate solution in test $\mathrm{V}_{2}=$ volume (in $\mathrm{mL}$ ) of thiosulphate solution in blank $\mathrm{W}=$ weight of sample

The saponification value was determined by dissolving $1 \mathrm{~g}$ of oil in $12.50 \mathrm{~mL}$ of ethanolic $\mathrm{KOH}$ and refluxing the mixture for 30 mins after which $1 \mathrm{~mL}$ of phenolphthalein indicator was added. The hot soap solution was then titrated with $0.50 \mathrm{M} \mathrm{HCl}$, while still hot. A blank determination was carried out under the same condition and the following equation was used to calculate the saponification value of the oil:

Saponifi-cation value $=56.1 \mathrm{M}\left(\mathrm{V}_{2}-\mathrm{V}_{1}\right) / \mathrm{W}($ Ajayi et al., 2004; AOAC, 1984)

where:

$\mathrm{M}=$ molarity of hydrochloric acid used

$\mathrm{V}_{1}=$ volume (in $\mathrm{mL}$ ) of hydrochloric acid used in test $\mathrm{V}_{2}=$ volume (in $\mathrm{mL}$ ) of hydrochloric acid used in blank $\mathrm{W}=$ weight of oil used

For the peroxide value, $1 \mathrm{~g}$ of the oil was weighed into a $200 \mathrm{~mL}$ conical flask and $25 \mathrm{~mL}$ of $2: 1 \mathrm{v} / \mathrm{v}$ glacial acetic acid and chloroform solvent was added. $1 \mathrm{~mL}$ of saturated potassium iodide solution [concentration in water] was then added. The mixture was titrated with $0.2 \mathrm{M}$ thiosulphate solution using $5 \mathrm{~mL}$ starch as indicator. A blank was processed similarly. The peroxide value of the oil was then calculated using the equation below:

Peroxide value $=100\left(\mathrm{~V}_{2}-\mathrm{V}_{1}\right) \mathrm{M} / \mathrm{W}$ (Ajayi et al., 2004; AOAC, 1984)

where:

$\mathrm{M}=$ molarity of thiosulphate

$\mathrm{V}_{1}=$ volume (in $\mathrm{mL}$ ) of thiosulphate solution in test $\mathrm{V}_{2}=$ volume (in $\mathrm{mL}$ ) of thiosulphate solution in blank $\mathrm{W}=$ weight of sample

The acid value of the oil was determined by dissolving $0.20 \mathrm{~g}$ of the oil in $2.5 \mathrm{~mL}$ of $1: 1 \mathrm{v} / \mathrm{v}$ ethanol and diethyl ether and titrating each with $0.1 \mathrm{M} \mathrm{NaOH}$ with swirling using phenolphthalein as indicator. The acid value was calculated as follows:

Acid value $=56.1 \mathrm{M}\left(\mathrm{V}_{2}-\mathrm{V}_{1}\right) / \mathrm{W}$

where:

$\mathrm{M}=$ molarity of $\mathrm{NaOH}$

$\mathrm{V}_{1}=$ volume (in $\mathrm{mL}$ ) of $\mathrm{NaOH}$ solution used in test

$\mathrm{V}_{2}=$ volume (in $\mathrm{mL}$ ) of $\mathrm{NaOH}$ solution in blank $\mathrm{W}=$ weight of sample

The colour and state of the oils at room temperature were noted by visual inspection. The refractive indices of the oils were determined using the Abbe refractometer (Baush and Lomb Thermo; Abbe 3L), while the specific gravity which was done at room temperature was estimated by the use of a specific gravity bottle following the method of Pearson (1976).

Metal composition. The metal composition of the seeds was determined following the method used by Idouraine et al. (1996), $1 \mathrm{~g}$ of each seed was dried- ashed in a muffle furnace at $550{ }^{\circ} \mathrm{C}$ for $5 \mathrm{~h}$ until a white ash was 
obtained. The minerals were extracted from ash by adding $3 \mathrm{~mL}$ of concentrated $\mathrm{HNO}_{3}(63 \%)$. The digest was carefully filtered into $100 \mathrm{~mL}$ standard bottle and made up to mark with distilled water. Minerals were estimated with the use of an atomic absorption spectrophotometer (Perkin Elmer model 703, USA). The instrument was calibrated with standard solutions containing known amounts of the minerals being determined, using analytical reagents; results are expressed in parts per million (ppm) of dry matter.

Fatty acid. The methyl esters of the crude oils were prepared in University of Tuebigen, Germany, following the method of Ajayi et al. (2002), $5 \mathrm{~mL}$ of $\mathrm{CH}_{3} \mathrm{OH}$ and $1 \mathrm{~mL}$ of $\mathrm{CH}_{2} \mathrm{Cl}_{2}$ were added to $0.10 \mathrm{~g}$ of each oil sample. Ice was used to cool the mixture and then $0.6 \mathrm{~mL}$ of $\mathrm{CH}_{3} \mathrm{COCl}$ was added, $1 \mathrm{~mL}$ of the solution was withdrawn into a hydrolysis tube and heated for $1 \mathrm{~h}$ at $110^{\circ} \mathrm{C}$. The solution obtained was again cooled with ice and discharged into a separating funnel containing $10 \mathrm{~mL}$ of $100 \% \mathrm{NaCl}$ solution. The extraction of the organics in the solution was carried out thrice with $4 \mathrm{~mL}$ of hexane; a rotatory evaporator was used to reduce the volume to $0.5 \mathrm{~mL}$ after which it was eluted on a silica gel column successively with $5 \mathrm{~mL}$ hexane and $4 \mathrm{~mL} \mathrm{CH}_{2} \mathrm{Cl}_{2}$. The volume was reduced to $1 \mathrm{~cm}^{3}$ by nitrogen gas prior to injection into $\mathrm{GC}$ for analysis. A separation was made of the $\mathrm{CH}_{2} \mathrm{Cl}_{2}$ fraction on a DB5 $30 \mathrm{~m} \times 0.25 \mathrm{~mm}$ capillary installed on a GC Chrompack 9001 (model: Chrompack 9001; city: Middelburg; country: Netherlands) equipped with computer software and mosaic integration. The column was operated under temperature programming conditions starting at $-35^{\circ} \mathrm{C}$ for $3 \mathrm{~min}$ after which it was increased at the rate of $20^{\circ} \mathrm{C} / \mathrm{min}$ to $230{ }^{\circ} \mathrm{C}$, where it was held for $5 \mathrm{~min}$. The internal standard used was heptadecanoic acid. The detector used was flame ionization detector.

Statistical analysis. Results are expressed as the means of three separate contents except for the mineral elements and fatty acids. The data were statistically analysed by student T-test. Means were compared by Duncan's (1955) at $5 \%$ level of significance $(\mathrm{P}=0.05)$.

\section{Results and Discussion}

Physical characterisation of E. pursaetha and $P$. macrophylla seeds has been shown in Table 1. These values are higher than the values reported in literature for other legumes (Ajayi et al., 2006). The oil content in P. macrophylla ( $40.29 \mathrm{~g} / 100 \mathrm{~g}$ dry matter) is almost 10 times higher in E. pursaetha ( $4.26 \mathrm{~g} / 100 \mathrm{~g}$ dry matter)
Table 1. Physical characterization of E. pursaetha and P. macrophylla seeds

\begin{tabular}{lll}
\hline \hline Property & E. pursaetha & P. macrophylla \\
\hline Weight of 100 seeds $(\mathrm{g})$ & 2645.50 & 1402.20 \\
Seed length $(\mathrm{cm})$ & 5.50 & 6.73 \\
Seed width $(\mathrm{cm})$ & 4.92 & 4.36 \\
\hline \hline
\end{tabular}

(Table 2). Further, it is higher than the value reported for G. mangostana (Ajayi et al., 2007) and some conventional oilseeds such as soybeans $(19.00 \pm 2.00$ $\%)$, olive $(22.51 \pm 2.50 \%)$, cotton $(19.50 \pm 1.00 \%)$, water melon seed $(35.7 \%)$ and rape $(42 \pm 3.0 \%)$ (Oyenuga and Fetuga, 1995); and is similar to previous findings of Omogbai (1990). Both seeds have high crude protein content, this is in close agreement with the protein in seeds of important legumes (Singh and Singh, 1992). The protein content of the two seeds indicates that they can contribute to the daily protein need of $23.6 \mathrm{~g} / 100 \mathrm{~g}$ dry matter for adults as recommended by the National Research Council (1974). The residue could also adequately serve as a source of protein for livestock feed. Both seeds have fairly high crude fibre content which is of nutritional significance since fibre helps to maintain the health of the gastrointestinal tract which has led to growing awareness for fibre consumption among the general public (Vijayakumari et al., 1997). Carbohydrate content of the seeds was found to be far greater in E.pursaetha ( $45.35 \mathrm{~g} / 100 \mathrm{~g}$ dry matter) than in P. macrophylla (3.84 $\mathrm{g} / 100 \mathrm{~g}$ dry matter). There was a significant difference in the ash content of the two seeds. The seeds can be kept for a long time without spoilage since both seeds have low moisture content of $9.00 \mathrm{~g} / 100 \mathrm{~g}$ dry matter for E. pursaetha and $6.32 \pm 1.05 \mathrm{~g} / 100 \mathrm{~g}$ dry matter for P. macrophylla. Table 3 summarizes the physical

Table 2. Proximate composition ${ }^{\mathrm{a}}$ of E. pursaetha and P. macrophylla $(\mathrm{mg} / 100 \mathrm{~g})$

\begin{tabular}{lll}
\hline \hline Composition $^{\mathrm{b}}$ & E. pursaetha $^{\mathrm{c}}$ & P. macrophylla $^{d}$ \\
\hline Oil yield & $4.26^{\mathrm{e}}$ & $40.29^{\mathrm{f}}$ \\
Moisture content & $9.00^{\mathrm{e}}$ & $6.32^{\mathrm{f}}$ \\
Ash content & $1.20^{\mathrm{e}}$ & $2.48^{\mathrm{f}}$ \\
Protein content & $23.19^{\mathrm{e}}$ & $32.10^{\mathrm{f}}$ \\
Fibre & $17.00^{\mathrm{e}}$ & $13.78^{\mathrm{f}}$ \\
Carbohydrate content & $45.35^{\mathrm{e}}$ & $3.84^{\mathrm{f}}$ \\
\hline \hline
\end{tabular}

${ }^{a}=$ values are means of triplicate determination; ${ }^{b, e, f}=$ values in the same horizontal row sharing different letter are significantly different at the $5 \%$ level; ${ }^{\mathrm{c}}=$ Oderinde and Ajayi (1998); ${ }^{\mathrm{d}}=$ Ajayi et al. (2002). 
properties of the seeds. Oil extracts from the two seeds are liquid at room temperature though one is light yellow and the other is golden yellow. The specific gravity of P. macrophylla compares well with the 0.91 value reported by Kamel et al. (1985) for watermelon seeds. Presented in Table 4 are some of the chemical properties of the crude oils extracted from E. pursaetha and $P$. macrophylla. Iodine value is a measure of the degree of unsaturation and it is a reflection of the amount of iodine needed to saturate the double bond. Both oils have their iodine value less than 100 and can therefore be classified as non-drying oils. They could be used for edible purposes. Saponification values were lower than those for coconut oil (248-265). Peroxide values, acid values and free fatty acids of both oil samples were significantly different from each other. It has been shown by Ekpa and Ekpe (1995), that unlike free fatty acid content which is a measure of free fatty acid present in a fat or oil, acid value is a measure of total acidity of the lipid involving contributions from all constituent fatty acids that make up the glycerides. Acid value takes into consideration the contribution of all the constituent fatty acids in the oil; it is the preferred quality control parameter used by paint manufacturers to monitor the concentrations of acids in resins. Both oils have low free fatty acid which is an indication that they could have long shelf lives (Dosumu and Ochu, 1995). The peroxide value of $P$. macrophylla is significantly higher than that of E. pursaetha. Fresh oils have been shown to have peroxide value to range from 20.0 to $40.0 \mathrm{mg} / \mathrm{g}$ oil (Pearson, 1976). The peroxide value of E. pursaetha is higher than the value reported for some underutilised legumes, while that of P. macrophylla is lower (Ajayi et al., 2006).

Table 5 shows the result for the evaluation of the mineral element constituents of both seeds. The copper, iron

Table 3. Comparison of the physical properties ${ }^{\mathrm{a}}$ of E. pursaetha and P. macrophylla seed oils

\begin{tabular}{|c|c|c|}
\hline Parameter $^{\mathrm{b}}$ & E. pursaetha ${ }^{c}$ & P. macrophylla ${ }^{d}$ \\
\hline State at RT* & Liquid & Liquid \\
\hline Colour & Light yellow & Golden yellow \\
\hline Viscosity (centipoise) & - & 19.55 \\
\hline Refractive index & $1.445^{\mathrm{e}}$ & $1.4695^{\mathrm{f}}$ \\
\hline Specific gravity & $0.8238^{\mathrm{e}}$ & $0.9150^{f}$ \\
\hline
\end{tabular}

Table 4. Comparison of the chemical properties ${ }^{\mathrm{a}}$ of E. pursaetha and $P$. macrophylla seed oils

\begin{tabular}{lll}
\hline \hline Parameter $^{\mathrm{b}}$ & \multicolumn{2}{l}{ E. pursaetha $^{\mathrm{c}}{\text { P. } \text { macrophylla }^{d}}^{\mathrm{e}}$} \\
\hline Acid value (mg/KOH/g oil) & $2.80^{\mathrm{e}}$ & $9.87^{\mathrm{f}}$ \\
Peroxide value (mg/g oil) & $22.00^{\mathrm{e}}$ & $5.97^{\mathrm{f}}$ \\
$\begin{array}{l}\text { Iodine value (mg/100g oil) } \\
\text { Free fatty acid }\end{array}$ & $25.00^{\mathrm{e}}$ & $63.14^{\mathrm{f}}$ \\
$\begin{array}{l}\text { Saponification value } \\
\text { (mg/KOH/g oil) }\end{array}$ & $1.41^{\mathrm{e}}$ & $4.96^{\mathrm{f}}$ \\
Esther value (m/KOH/g oil) & $191.20^{\mathrm{e}}$ & $151.42^{\mathrm{f}}$ \\
\hline \hline
\end{tabular}

$\overline{\mathrm{a}}=$ values are means of triplicate determination; ${ }^{\mathrm{b}, \mathrm{e}, \mathrm{f}}=$ values in the same horizontal row sharing different letter are significantly different at the $5 \%$ level; ${ }^{*}=\%$ as oleic acid; $\mathrm{c}=$ Oderinde and Ajayi (1998); ${ }^{\mathrm{d}}=$ Ajayi et al. (2002).

and zinc contents found in both seeds are low and cannot meet the required amounts necessary for a healthy diet (Negretti et al., 1995). However, potassium, which is the most prevalent mineral element in both seeds, is high. Potassium is essential as an activator for enzymes involved in the synthesis of certain peptides bonds from functions in the synthesis of chloroplastic protein and may impair the machinery for chlorophyll synthesis (Alabi, 1987). The quantity of calcium in both seeds is reasonable. Calcium is important in cell wall formation and in the formation of cell membranes and lipid structures and it is also involved in normal mitosis thus, ensuring non-occurrence of abnormalities in seeds and plants (Delving, 1975). Magnesium which is the next most prevalent mineral element in both seeds is an important constituent of chlorophyll molecules which ensures non-discolouration of young seedlings (Alabi and Alausa, 2006). Taking into consideration the various physiological contributions of these mineral nutrients, it may be deduced that both seeds can supply reasonable

Table 5. Comparison of the mineral element composition of E. pursaetha and P. macrophylla

\begin{tabular}{lll}
\hline \hline Element $^{\mathrm{a}}$ & E. pursaetha $^{c}$ & P. macrophylla $^{\mathrm{d}}$ \\
\hline Sodium & 1.30 & 1.02 \\
Potassium & 109.76 & 128.85 \\
Magnesium & 21.56 & 8.07 \\
Calcium & 11.37 & 2.84 \\
Zinc & N.D & 0.65 \\
Copper & 0.26 & 0.25 \\
Manganese & 0.11 & 1.37 \\
Iron & 0.29 & 6.00 \\
\hline \hline
\end{tabular}

$\overline{\mathrm{a}}=$ Oderinde and Ajayi (1998); ${ }^{\mathrm{b}}=$ N.D - not determined;

${ }^{\mathrm{c}}=$ Oderinde and Ajayi (1998); ${ }^{\mathrm{d}}=$ Ajayi et al. (2002). 
quantity of these mineral elements if consumed. This is however, subject to testing the toxicity of the seed.

The oil extracts from the seeds of both E. pursaetha and P. macrophylla are highly unsaturated (Table 6). The fatty acid composition reveals that oleic acid ( $E$. pursaetha: $47.80 \%$; P. macrophylla: $28.17 \%$ ) and linoleic acid (E. pursaetha: $30.40 \%$; P. macrophylla $35.76 \%$ ) are the predominant unsaturated fatty acids. The mono and polyunsaturated fatty acids together account for $78.20 \%$ (E. pursaetha) and $63.93 \%(P$. macrophylla) of the total fatty acids in the two oil extracts. This particular finding is encouraging because it is a desirable feature in human food (Vijayakumari et al., 1997). The saturated/ non-unsaturated/ polyunsaturated fatty acids balance 21.20/48.40/30.40 for E. pursaetha and 24.80/28.17/35.76 for P. macrophylla approaches that of Tylosema fassoglensis sample from Burundi (28/36/36) (Dubois et al., Dosunu and Ochu, 1995) and peanut oil (22/39/39) (INRA, 1987). Linoleic acid, which is an essential fatty acid, was found to be higher in P. macrophylla (35.76\%) than E. pursaetha $(30.40 \%)$. Linolenic acid was not detected in the two seeds nevertheless high molecular weight homologues $\left(\mathrm{C}_{22}\right.$ - $\left.\mathrm{C}_{26}\right)$ unambiguously identified by GC Chrompack 9001 were found in small quantities in P. macrophylla

Table 6. Comparison of the fatty acid composition of E. pursaetha and P. macrophylla seed oils

\begin{tabular}{lll}
\hline \hline Fatty acid $^{\mathrm{a}}$ & E. pursaetha $^{b}$ & ${\text { P. } \text { macrophylla }^{c}}$ \\
\hline $\mathrm{C}_{16: 0}$ & 17.10 & 3.83 \\
$\mathrm{C}_{16: 1}$ & 0.60 & - \\
$\mathrm{C}_{18: 0}$ & 4.10 & 0.67 \\
$\mathrm{C}_{18: 1}$ & 47.80 & 28.17 \\
$\mathrm{C}_{18: 2}$ & 30.40 & 35.76 \\
$\mathrm{C}_{20: 0}$ & - & 1.47 \\
$\mathrm{C}_{20: 1}$ & 78.20 & 0.74 \\
$\mathrm{C}_{20: 2}$ & - & 0.88 \\
$\mathrm{C}_{20: 3}$ & - & $4: 34$ \\
$\mathrm{C}_{22: 0}$ & 63.93 & 3.94 \\
$\mathrm{C}_{22: 1}$ & - & 1.60 \\
$\mathrm{C}_{22 ; 2}$ & - & 3.71 \\
$\mathrm{C}_{24: 0}$ & - & 12.52 \\
$\mathrm{C}_{26: 0}$ & - & 2.37 \\
$\%$ Total saturated & & \\
fatty acid & 21.20 & 24.80 \\
$\%$ Total unsaturated & & \\
fatty acid & 78.80 & 75.20 \\
\hline \hline a $=$ percentage of dry matter &
\end{tabular}

but not in E. pursaetha. Also present in P. macrophylla but not in E. pursaetha are $\mathrm{C}_{20: 3}$ series of fatty acids. The unsaturated ratio in the oil extracts from the two seeds were high. Polyunsaturated fatty acids play an important role in modulating human metabolism (GuilGuerro et al., 1998). The high levels of unsaturated acids found in both seeds are comparable to the values reported for $M$. flagellipes (Ajayi et al., 2006). The main saturated fatty acids in E. pursaetha is $\mathrm{C}_{16: 0}(17.10$ $\%$ ) while that of $P$. macrophylla is $\mathrm{C}_{24: 0}(12.52 \%)$.

\section{Conclusion}

The seeds from E. pursaetha and P. macrophylla are both rich in protein and mineral elements; however, seeds from $P$. macrophylla are very rich in oil while that of E. pursaetha are not. The carbohydrate content of the seeds of E. pursaetha suggests its usefulness as feed supplement while both seeds could be considered as good sources of dietary fibre. The free fatty acids of both oils were below the maximum desirable limit of $5.0 \%$. Iodine values of the oils indicate the probability of their being suitable as edible oils. The peroxide value of P. macrophylla is low but that of E. pursaetha is high, it will need to be refined before it can be consumed. Oils from both seeds contain linoleic acid which is one of the essential fatty acids. They are highly unsaturated which makes them nutritionally important; they can be used to lower cholesterol level in human if consumed. This is however subject to testing for the toxicity of the oils. The overall result showed that the two oils have potential for use as edible oils and industrial purposes.

\section{Acknowledgement}

The author wishes to thank University of Ibadan and International Institute for Tropical Agriculture, Ibadan, Nigeria, for their facilities.

\section{References}

Ajayi, I.A. Oderinde, R.A., Ogunkoya, B.O, Egunyomi, A., Taiwo, V.O. 2007. Chemical analysis and preliminary toxicological evaluation of Garcinia mangostana seeds and seed oil. Food Chemistry, 101: 999-1004.

Ajayi, I.A., Oderinde, R.A., Kajogbola, D.O., Uponi J.I. 2006. Oil content and fatty acid composition of some underutilized legumes from Nigeria. Food Chemistry, 99: 115-120.

Ajayi, I.A., Dawodu, F.A., Adebowale, K.O., Oderinde, R.A. 2004. A study of the oil content of Nigerian grown Monodora myristica seeds for its nutritional and industrial applications. Pakistan Journal of 
Scientific and Industrial Research, 47: 60-65.

Ajayi, I.A., Dawodu, F.A., Adebowale, K.O., Oderinde, R.A. 2002. Chemical composition of Pentaclethra macrophylla seeds and seed oil grown in Nigeria. $L a$ Rivista Italiana Delle Sostanze Grasse, 76: 183-185.

Alabi, D.A., Alausa, A.A. 2006. Evaluation of the mineral nutrients and organic food contents of the seeds of Lablab purpureus, Leucaena leucocephala and Mucuna utilis for domestic consumption and industrial utilization. World Journal of Agricultural Science, 2: 115-118.

Alabi, D.A. 1987. Proximate analysis of food and mineral contents of eleven cultivars of okra (Abelmoschus esculentus (L) Moench). Proceeding of Horticultural Society of Nigeria, 9: 75-83.

AOAC, 1984. Official Methods of Analysis. $14^{\text {th }}$ edition, Association of Official Analytical Chemists, Arlington, VA, USA.

Asoegwu, S.N., Ohanyere, S.O., Kanu, O.P., Iwueke, C.N. 2006. Physical properties of African oil bean seed (Pentaclethra macrophylla). Agricultural Engineering International: the CIGR Ejournal. Manuscript FP 05006.

Delving, A.M. 1975. Detection occurrence and availability of the essential elements. In: Plant Physiology, pp. 305-325, $3^{\text {rd }}$ edition, D. Van Nustrand Company, NY, USA.

Dosumu, M.I., Ochu, C. 1995. Physicochemical properties and fatty acid composition of lipids extracted from some Nigerian fruits and seeds. Global Journal of Pure and Applied Science 1: 45-50.

Duncan, D.B. 1955. Multiple range and multiple F tests. Biometrics, 11: 1-42.

Ekpa, O.D., Ekpe, U.J. 1995. The effect of coconut oil concentration and air exposure to the total acidity of palm oil. Global Journal of Pure and Applied Sciences, 1: 51-58.

Guil-Guerrero, J.L., Gimenez- Gimenez, A., RodriguezGarcia, I., Torja-Isasa, M. E. 1998. Nutritional Composition of Sonchus species (S. asper L, $S$. oleraceus and S. tenerrimus L). Journal of Science Food and Agriculture, 76: 628-632.

Idouraine, A., Kohlhepp, E.A., Weber, C.W. 1996. Nutrient constituents from eight lines of naked seed squash (Cucurbita pepo L.). Journal of Agricultural Food Chemistry, 44: 721-724.

Kamel, B.A., Dawson, H. 1985. Characteristics and composition of melon and grape seed oils and cakes. Journal of American Oil Chemical Society,
62: 917-923.

Keay, R.W.J. 1989. Nigerian Trees, 476 pp., Claredon Press, Oxford, UK.

Mbajunwa, O.K., Akingbala, J.O., Mulongoy, K., Oguntimein, G. 1998. Starter culture evaluation for the production of ugba from African oil bean seed Pentaclethra macrophylla. Journal of Science Food and Agriculture, 77: 127-132.

Mbajunwa, O.K. 1995. Effect of processing on some antinutritive and toxic components and on the nutritional composition of the African oil bean seed (Pentaclethra macrophylla Benth). Journal of Science Food and Agriculture, 68: 153-158.

NRC, 1974. Recommended dietary allowances. National Research Council. Food and Nutrition Board, 128 pp., National Academic Press, USA.

Negretti, de B.V., Bratter, P., Mohn, L., Sitzer, G. 1995. Minerales y Oligoelementos. Aspectos Generals Analisis Clinico/Fundacion Bertelsmann. Gütersloh: Editorial Fundacion. Bertelsmann, Germany.

Oderinde, R.A., Ajayi, I.A. 1998. Composition of Entada pursaetha seed and seed oil grown in Nigeria. $L a$ Rivista Italiana Delle Sostanze Grasse, 75: 457- 459.

Odoemelam, S.A. 2005. Proximate composition and selected physicochemical properties of the seeds of African oil bean (Pentaclethra macrophylla). Pakistan Journal of Nutrition, 4: 382-383.

Okafor, J.C., Fenandez, E.C. 1987. Compound farms of Southeast Nigeria. A predominant agroforestry homegarden system with crops and small livestock. Agroforestry Systems, 5: 153-168.

Omogbai, F.E. 1990. Lipid composition of tropical seeds used in the Nigerian diet. Journal of Science Food and Agriculture, 50: 253-255.

Oyenuga, V.A., Fetuga, B.L. 1975. Some aspects of the biochemistry and nutritive value of water melon seed (Citrus vulgaris). Journal of Science Food and Agriculture, 26: 843-845.

Pearson, D.A. 1976. Chemical Analysis of Foods, pp. $422-511,7^{\text {th }}$ edition, Edinburg Churchill, Livingstone, London, UK.

Singh, U., Singh, B. 1992. Tropical grain legumes as important human foods. Economic Botany, 46: 310-321.

Vijayakumara, K., Siddhuraju, P., Janardhunan, K. 1997. Chemical composition, amino acid content and protein quality of the little-known legume (Bauhinia purpurea L). Journal of Science Food and Agriculture, 73: 279-286. 